\title{
Teachers' Personality in the Process of Education
}

\author{
Milan Jozek ${ }^{*}$
}

\begin{abstract}
There is something in everyone that does not change. The personality of a teacher or an educator stays in the centre of educational work. The personal contact and dialogic disposition of a teacher helps to form the personal potential of a human being to overcome the difficulties and contribute to the optimal functioning in a social environment. The process of learning and the growth of personality belong to a category of interpersonal relationships. A very strong emphasis is placed on the so called "methods of dialogue", which can not only reduce destructive influences, but also teaches us how to accept criticism in a non-offensive way. Everything should take place in an open climate without judgement.
\end{abstract}

Key words: educational system, personality and personal contact, formative process, dialogue.

This paper points out the importance of personal contact and dialogue, or, better said, the importance of participatory aspects of personal freedom, subjective tendencies and intention in the process of education. In every person, there is something that does not change. The youth of today is the same as it was several years ago. In the past, the young generation was influenced and shaped by the painful experience of war, concentration camps and constant danger. Such experiences created heroic qualities of the young. In order to achieve a complete integration of all social classes into the educational system, there has to be constant pedagogical modification of education.

The pedagogical modifications of the educational system are closely connected with the acquisition of personal contacts and their nature. In the process of education, this need calls for modifications in the traditional teaching methods, especially in communication between the educator and the student. A short indepth analysis will help to reach an optimal line.

There are some functions that have to be taken into consideration as early as possible when modifying pedagogic preparations and approaches. An effective coordination of educational activities, especially during school, plays an important role in the educational process. Another crucial aspect is psychopedagogical aid, i.e. a kind of problem-solving consultancy for the youth. Then,

Milan Jozek, Constantine the Philosopher University in Nitra, Nitra, Slovakia; mjozek@ukf.sk 
it is important to mention assistance with integration of students into youth organizations, interest groups and fellowships.

The emphasis needs to be placed on the practical side of the educational and formative process. All of the above mentioned aspects are to play an important role in the process of education. The general evolution of mankind is closely connected with the subject as well as the methods of education. Such findings serve as a basis of the following research: In ancient Egypt, as well as in other ancient civilisations, we come across a process of educational diversity. This process was based mostly on intuition. The platform of methodology must not be based on a kind of uniformity or political indoctrination that would allow somebody to rule over others. In many cases, the process of formation and education requires an individual approach in which dialogue, as a type of contact, plays an important role. Nowadays, the media informs us about events that change and influence our lives. Intense and rapid changes in education are also conditioned by science and technological development, changes in the value system and lifestyle. In the course of the formative process, there is evidence of growing pressure put on teachers, especially connected with persons who suffer from social and mental dysfunctions. Therefore, it is important that, whenever necessary, teachers should be able to serve as consultants. A crucial stage of this process is the ability of the teacher to help students with mental and spiritual questions. Education is no longer understood as a process in which students are to be prepared for life in society to overcome obstacles of life, or values and norms that differ from their previous experience. It is understood as a process that should help students to develop themselves, to help them overcome obstacles and lead a productive life in a social and natural environment (Klapa, 1994, p. 28). The cultural aspect of education is important, too, i.e. process of handing down values and methods to students. Patriotism, which aims to help students form a sense of love for their country, plays a significant role as well. It is also important to prepare students for the fulfilment of social duties of a citizen, employee or consumer. Obviously, such roles stand at the intersection of politics, ideology, culture and family. There is a certain amount of danger in situations when we teach students to fulfil their daily obligations. A fully realized person becomes a passive recipient of information, a villain; here the formative process can be understood as a process of discharging strictly defined obligations. It is necessary to state that education is not only for the "inflexible and resistant".* It is crucial to respect the biological and psychological qualities, the ones we inherit from our parents and ancestors.

In the process of education and formation, where the dialogue is the priority, the style of education also plays an important role. Thus, education can be divided based on its intrinsic and extrinsic characteristics. A renowned specialist in this

\footnotetext{
* By inflexible and resistant we mean those who are not able to adapt; the members of so called "problem groups" (the author's note)
} 
field is Stanislaw Kuczkowski. The autocratic style of education is defined as education based on fear with an existing distance between the educator and the student (child), sometimes marked with cordiality. Other accompanying features of this style of education are being strict, delivering punishment, yelling at students, making threats, not fulfilling the student's desires, creating feelings of fear, shame and infringing upon the student's personal liberty, lack of coordination of their activities, not controlling the tasks to be completed, lack of consultation in the process of decision making by the educator, lack of justification, the dominance of punishment over praise, showing disregard for the student's will and desire, subordination of the student based on respect. As a result, the student (pupil) acquires the norms of behaviour only superficially, without internalization. The democratic style of education is based on mutual communication between the child and their family members. They talk about common, everyday matters and organize their free time activities and holidays. Children express their opinions and take part in decision making. Regulation of the child's behaviour is without punishment. Children are not forced to do their duties and tasks; on the contrary, they freely accept them. Instead of punitive tools, this style prefers explanation of improper behaviour. Closely connected with it is the inner discipline of the child and discipline based on norms and moral principles that have been internalized." In liberal education, the child is given complete freedom, independent activity and spontaneous development. Intervention is made only in cases of serious disrespect of social norms. An accompanying feature is a delayed process of the child's socialization as well as the internalization of moral norms. In many cases this results in the child's egocentrism (Kuczkowski, 1985, pp. 234-235). Distance education is difficult. A pro-active formation requires active personal participation and a progressive methodology. No ready-made rules will help. Parenting guides which one often comes across in newspapers and magazines, are mostly a publicity stunt. The teacher's personality remains the most crucial variable in education. The teacher must not be a leader or a commander (Klapa, 1994, p. 38) but an adviser. The human personality is formed in a complex structure of educational processes viewed as a whole. In this structure, the process of moral education has a universal position. It influences the whole personality and it is the basic requirement of human moral maturity. This creates an essential humanistic and cultural value of an educated being. The process of value formation is characterized by active searching, discovering, acceptance and identification (Žilínek, 1997, pp. 61-68).

When considering an appropriate method or form, it is essential to take into consideration the following factors: who the student is; what his/her characteristic features are, what expectations and needs he has got; in what

\footnotetext{
* To internalize means the inner acceptation and harmony of moral principles and norms. (the author's note)
} 
conditions he/she lives and will live; what social, family and coeval environment he/she lives in; and what value system he/she has acquired so far. Then, it is crucial to consider who we, the teachers are, what our characteristic features are, what professional training we have received, what we expect from our students, and what we are able to offer them. Moreover, we ought to ask ourselves what relationship we have with a particular student, when and under what conditions we have got to know each other, what was our first impression and evaluation of the student, how much time we are able to spend with the student, and when and in what way our relationship have changed (e.g. due to leaving school, change of the workplace). Then, it is important to pay attention to the influence of other people on the student, e.g. parents, teachers, peers, or whether our efforts are in concordance with their influence. Furthermore, we have to take into account with whom we can cooperate, what type of cooperation it will be and of what duration. We also have to consider who and in what ways can complicate our procedures. As a result, it is crucial to ask what goals we want to achieve in education, what we wish to change and what aspects should not be changed. Then, we ought to consider which goals might appear in the future as unfavourable for students, for example an excessive fixation on himself/herself. An effective educational process requires acceptance of the youth, showing them respect, having an understanding of them and empathising with them. These are serious and difficult goals, especially at the beginning of the educational process and after the first failures. However, their absence leads to hostility and aggression between teachers and students or classmates. Another condition for an effective educational process is that the teacher's actions are in accordance with his/her convictions. It is called authenticity. Those teachers who act against their convictions, end up playing self-centred, tragic roles for their own sake, and, probably, even without realizing it (Klapa, 1994, p. 40*). The educational process and personal development are a part of interpersonal relationships. Students gradually become aware of the fact that their experiences are based on their contacts and encounters with other people. This realisation should lead to the appreciation of others. It should help students respects the lives of others as well as activities, politics and structures that help or complicate the mutual development. However, this is possible only if teachers are aware of these values and are faithful to them (Pedagogia Ignacjańska, 1994, p. 27). The reality of present-day life helps us understand the overall importance of constant education not only for children but for adults, too. A part of the difficulties parents come across, taking account the cultural context, is the preparation of their children for life, directing them so they are able to see and accept "the real world", the sense of sexuality, the value of humans and free acceptance of moral principles. Inspite of the fact that in the past culture was interwoven with reverence for

\footnotetext{
* In this section the author talks about methods and forms of education where the most important the teacher's personality is and not an aggressor or a promised reward.
} 
basic moral principles and it served to maintain and guard them, children were not informed about these things. The traditional models of behaviour lost their influence, which resulted in the fact that children lost clear rules. This is why parents may feel unprepared to give children appropriate answers, which causes parents to disqualify themselves from the active formative process of development (Jozek, 2004). Therefore, it is becoming crucial that everyone who accepts the function of managing any element in the educational and formation process, should not forget about the style and the method used - dialogue. Consequently, they ought to take into account the characteristic features of both teachers and students, or environmental conditions (Klapa, 1994, p. 41). The condition of social existence is the communicative aspect of human nature; however, it is not its essence. The inner desire to share information and values with others or to receive them back has a specific intention. First of all, the aim is to create a better unity between comprehension and action, in other words to achieve social unity. This type of social unity is conditioned by the character of communication. Communication always presupposes unity. Therefore, by definition, social actions are teleological. It means that there is a certain intention; in other words, they head towards realization of thoughts or ideals of social unity.

\section{References:}

JOZEK, M. Morálne základy rodiny vo sfére formačného procesu nového pokolenia. Člověk - Dějiny - Hodnoty II. Sborník materiálů z mezinárodní konference v dnech 23.-24. zárí 2004, Ostrava, Repronis, 2005.

DZIEKOŃSKI, S. Dydaktyka w stużbie katechezy. Kraków, 2002.

Etika a etická výchova vškolách, Zborník vedeckej konferencie $\mathrm{s}$ medzinárodnou účast'ou poriadanej pri príležitosti 10 . výročia obnovenia Trnavskej univerzity v Trnave. Trnava: Trnavská univerzita v Trnave, 2002.

KLAPA, W. Wybrane zagadnienia wychowania dzieci i młodzieży. ŚNIEŻYŃSKI, M. (ed.) Katecheta w szkole, Poradnik pedagogiczny. Kraków, 1994.

KONDRLA, P., BLAŠČÍKOVÁ, A. et al. Vybrané kapitoly didaktiky náboženskej výchovy. Nitra: FF UKF, 2004.

KUCZKOWSKI, S. Przyjacielskie spotkania wychowawcze. Kraków, 1985.

BARCIŃSKI, Z. and WÓJCIK, J. (eds.). Metody aktywizujace w katechezie I., Praca zbiorova. Lublin, 1999.

ŽILÍNEK, M. Étos a utváranie mravnej identity osobnosti. Bratislava, IRIS, 1997.

Pedagogia Ignacjańska, Podejście praktyczne, Warszawa, 1994. 